\title{
Analisis Hukum Penjatuhan Sanksi Administratif Terhadap Notaris oleh Majelis Pengawas Notaris
}

\author{
Legal Analyzing on Administrative Sanction towards Notary-by-Notary \\ Supervisor Council
}

\author{
Mim Nasrah Rasyid \\ Kantor Wilayah Kementerian Hukum dan HAM Sulawesi Tenggara \\ E-mail: mimnasrahrasyid@gmail.com \\ Muhammad Jufri Dewa \\ Pascasarjana Universitas Halu Oleo \\ E-mail: muh.jufridewa@yahoo.com \\ Muhammad Sabaruddin Sinapoy \\ Pascasarjana Universitas Halu Oleo \\ E-mail: sabaruddinsinapoy@yahoo.com
}

\begin{abstract}
This research addressed at analyzing the evidences of Notary Supervisor Council towards on notary who double occupied with an attorney. Considering the legal factors of Notary Supervisor Council's judgment that punished on notary who has double occupied the attorney. This paper used a legal research by applying legislations, conceptual, and cases approach. This study revealed the answer that Notary Supervisor Council has a legal power in inspecting for offender behavior and his or her position. The interpretation of Region Supervisor as well Center Supervisor that the notary who has double occupation is categorized as a heavy violation, but there are differences imposition of sanctions at each level of the Notary Supervisor Council.
\end{abstract}

Keyword: Notary; Sanctions; Supervising

Abstrak: Penelitian ini ditujukan untuk menganalisis pembuktian Majelis Pengawas Notaris terhadap notaris merangkapjabatan sebagai advokat. Menganalisis faktor-faktor yang menjadi pertimbangan hukum bagi majelis pengawas notaris dalam menjatuhkan sanksi administratif terhadap notaris yang terbukti merangkap jabatan sebagai advokat. Penelitian ini adalah penelitian hukum yang menggunakan pendekatan perundangundangan, konseptual, dan kasus. Penelitian ini menjawab masalah yakni Majelis Pengawas Notaris berwenang untuk memeriksa pelanggaran perilaku dan pelaksanaan jabatan notaris. Majelis pengawas notaris menafsirkan bahwa notaris merangkapjabatan sebagai advokat dikategorikan sebagai pelanggaran berat, namun terdapat perbedaan pada penerapan sanksinya berdasarkan karakteristik putusan di setiap tingkatan Majelis Pengawas Notaris.

Kata kunci: Notaris; Sanksi; Pengawasan 


\section{PENDAHULUAN}

Konsep hukum administrasi negara menjelaskan setiap tindakan atau perbuatan pemerintah harus berdasarkan hukum karena dalam negara hukum terdapat prinsip wetmatigheid van bestuur atau asas legalitas. ${ }^{1}$ Hal ini pun berlaku dalam pembinaan dan pengawasan terhadap notaris. Notaris berpedoman pada UUJN dan peraturan pelaksananya dalam menjalankan profesinya. Salah satu pokok bahasan dalam penelitian ini adalah pelanggaran ketentuan larangan terhadap notaris yang diatur dalam Pasal 17 e UUJN yang memuat bahwa notaris dilarang merangkap jabatan sebagai advokat.

Keberadaan notaris di Provinsi Sulawesi Tenggara mengalami perkembangan yang sangat pesat. Hingga 31 Desember 2020, Provinsi Sulawesi Tenggara yang terdiri dari 15 (lima belas) Kabupaten dan 2 (dua) Kota, telah memiliki 82 orang notaris yang tersebar di 13 (tiga belas) Kabupaten dan 2 (dua) Kota. Ada 4 (empat) Kabupaten yang belum memiliki notaris sampai saat ini. Berdasarkan data dari Majelis Pengawas Wilayah Notaris Sulawesi Tenggara, ada Notaris di Provinsi Sulawesi Tenggara yang terbukti dan dinyatakan melakukan pelanggaran UUJN dengan merangkap jabatan sebagai Advokat ${ }^{2}$. Dalam proses pemeriksaan Notaris tersebut oleh Majelis Pengawas Notaris, permasalahan muncul pada saat penjatuhan sanksi. Dalam UUJN, tidak ada ketentuan yang secara eksplisit mengatur mengenai jenis sanksi yang dapat dikenakan kepada Notaris yang rangkap jabatan sebagai Advokat, dan belum ada ketentuan yang secara jelas mengatur mengenai jenis pelanggaran berat yang dimaksud dalam Peraturan Menteri Hukum dan HAM Nomor 61 Tahun 2016 tentang Tata Cara Penjatuhan Sanksi Administratif terhadap Notaris. Hal inilah yang menimbulkan permasalahan karena adanya perbedaan penafsiran di antara para Anggota Majelis Pengawas Notaris, sehingga tidak ada kepastian hukum terhadap penerapan sanksi bagi Notaris merangkap sebagai Advokat.

Adanya perbedaan penafsiran antara Majelis Pengawas Notaris menyebabkan sistem penjatuhan sanksi bergantung kepada subjektivitas penilaian Majelis Pengawas Notaris. Selain itu, secara yuridis normatif, tidak ada ketentuan yang mengatur mengenai pada saat kapan terjadi rangkap jabatan notaris dan advokat. Apakah seorang notaris dianggap melakukan rangkap jabatan pada saat dilantik menjadi advokat ataukah pada saat notaris yang bersangkutan menjalankan tugas sebagai advokat secara nyata. Perbedaan penafsiran tersebut terjadi karena adanya norma yang kabur dan multitafsir yang termuat dalam Undang-Undang

1 Muh. Jufri Dewa, Hukum Administrasi Negara dalam Perspektif Pelayanan Publik, Kendari: Unhalu Press, 2011, hlm. 114.

2 Wawancara dengan Maktub S.H., M.H. selaku Wakil Ketua MPW Sulawesi Tenggara, 16 Oktober 2020. 
Jabatan Notaris dan peraturan pelaksananya. Berdasarkan uraian tersebut, maka peneliti melakukan penelitian dengan judul “Analisis Hukum Penjatuhan Sanksi Administratif Terhadap Notaris Merangkap Sebagai Advokat oleh Majelis Pengawas Notaris."

\section{METODE PENELITIAN}

Penelitian ini menggunakan tipologi penelitian hukum normatif. Penelitian hukum normatif yaitu penelitian hukum sebagai norma. Penelitian hukum dilakukan untuk menghasilkan argumentasi, teori atau konsep hukum sebagai preskripsi untuk menyelesaikan masalah yang dihadapi. Dengan demikian penelitian ini mencakup analisis hukum tertulis yang didahului inventarisasi hukum positif. Hal ini akan menjadi salah satu produk analisa abstraksi dari norma hukum positif. ${ }^{3}$ Tipe penelitian yang digunakan yaitu penelitian doktrinal (doctrinal research) dan penelitian teoretik (theoritical research). ${ }^{4}$ Bahan hukum yang digunakan dalam penelitian ini meliputi bahan hukum primer dan sekunder.

\section{ANALISIS DAN PEMBAHASAN}

\section{Kewenangan Majelis Pengawas Notaris dalam Memeriksa dan Menjatuhkan Sanksi Administratif Terhadap Notaris}

Salah satu kewajiban negara yakni memberikan dan menjamin adanya kepastian hukum bagi para warga anggota masyarakat. Negara memberikan kewenangan secara atributif kepada notaris sebagai pejabat umum untuk melaksanakan sebagian fungsi publik dari negara yaitu dalam hubungan hukum masyarakat dengan membuat alat bukti tertulis berupa akta autentik. Luasnya kewenangan yang diberikan kepada Notaris mengakibatkan perlunya pengawasan agar Notaris tetap dapat menjalankan jabatannya dengan baik serta meningkatkan pelayanan dan perlindungan hukum bagi masyarakat pengguna jasa Notaris ${ }^{5}$.

Berdasarkan Pasal 67 UUJN, pengawasan atas notaris dilakukan oleh Menteri Hukum dan HAM yang didelegasikan kepada Majelis Pengawas Notaris yang terdiri dari 3 (tiga) unsur yakni Pemerintah, Akademisi, dan Notaris. Pasal ini memberikan kewenangan kepada Majelis

3 Soentandyo Wingyosoebroto, Penelitian Hukum, Surabaya, Surabaya: Pusat Studi Hukum dan Pembangunan Fakultas Hukum UNAIR, 1974, hlm. 1, 7, dan 8.

4 Peter Mahmud Marzuki, Penelitian Hukum, edisi revisi cetakan Ke-13, Jakarta: Kencana, 2017, hlm. 133.

5 Arifa Fatmalina, Roesnatiti Prayitno, Widodo Suryandono, "Notaris yang Berulang Kali Melakukan Pelanggaran Setelah Dijatuhi Sanksi oleh Majelis Pengawas Notaris (Analisis Putusan Majelis Pemeriksa Pusat Notaris Tanggal 09 Oktober 2018 Nomor 03/B/MPPN/X/2018 dan Putusan Majelis Pemeriksa Wilayah Notaris Provinsi Jawa Barat Tanggal 26 Februari 2007 Nomor 129/MPW-JABAR/2007)", Notary Indonesian Universitas Indonesia, Vol 1, No 002, 2019, hlm. 2. 
Pengawas untuk melakukan pengawasan terhadap Notaris, termasuk pemeriksaan jika terjadi pelanggaran UUJN hingga penjatuhan sanksi administratifnya sesuai dengan mekanisme dan prosedur yang telah ditetapkan.

Kewenangan merupakan aspek yang sangat penting dalam proses pemeriksaan notaris karena jika hal ini tidak terpenuhi, maka akan mengakibatkan cacat prosedural dalam pemeriksaan notaris sehingga putusan yang dihasilkan dapat batal demi hukum. ${ }^{6}$ Jika pemeriksaan yang dilakukan cacat prosedur, maka hal ini dapat menjadi preseden buruk bagi Majelis Pengawas Notaris. Hal ini pula yang menjadi salah satu materi dalam pengajuan banding atas putusan MPW oleh Notaris M.H sebagaimana termuat dalam memori bandingnya yaitu:

"bahwa MPD Kota Kendari dan MPW Sulawesi Tenggara telah keliru dalam mempertimbangkan kewenangannya dalam memeriksa dan mengawasi saya sebagai notaris, sebagaimana disebutkan dalam Pasal 21 Peraturan Menteri Hukum dan HAM Nomor M.02.PR.08.10 Tahun 2004 dijelaskan bahwa kewenangan Majelis Pengawas meliputi:
a. administratif yang tidak memerlukan persetujuan rapat Majelis Pengawas;
b. administratif yang memerlukan persetujuan rapat Majelis Pengawas;
c. melakukan pemeriksaan rutin;
d. melakukan pemeriksaan terhadap dugaan adanya pelanggaran jabatan dan perilaku Notaris.

Sehingga pemeriksaan ini harus berdasarkan laporan dari masyarakat. Sedangkan yang termuat dalam BAP MPD Kota Kendari menyebutkan bahwa saya adalah "terperiksa", bukan "terlapor". 7

Menurut peneliti, jika dikaji secara normatif, pemeriksaan terhadap notaris yang diduga melanggar UUJN adalah merupakan kewenangan Majelis Pengawas Notaris. Hal ini berdasarkan Pasal 18 Permenkumham Nomor 15 Tahun 2020 tentang Tata Cara Pemeriksaan Majelis Pengawas Terhadap Notaris, bahwa pemeriksaan oleh Majelis Pemeriksa Daerah meliputi:
a. laporan pengaduan masyarakat;
b. pemeriksaan protokol notaris; dan/atau
c. fakta hukum terhadap dugaan pelanggaran pelaksanaan jabatan dan perilaku notaris.

Berdasarkan Pasal 18 tersebut, maka adanya pengaduan masyarakat sebagaimana dimaksud dalam butir a merupakan hal yang terpisah dan berbeda dengan pemeriksaan karena

\footnotetext{
6 Nur Cahyanti, Budi Raharjo, Sri Endah Wahyuningsih, "Sanksi Terhadap Notaris Yang Melakukan Tindak Pidana Menurut Peraturan Perundang-Undangan di Indonesia", Jurnal Akta, Volume 5, Nomor 1, Maret 2018,

7 Berdasarkan memori banding Notaris M.H. kepada MPP Nomor M.25/Reg.Banding/MPPN/06/2020.
} 
adanya dugaan pelanggaran pelaksanaan jabatan dan perilaku notaris sebagaimana dimaksud dalam butir c. Asumsi Notaris M.H yang mendasarkan bahwa dugaan pelanggaran UUJN hanya bisa diproses oleh MPD karena adanya laporan masyarakat, menurut peneliti tidak dapat dijadikan alasan keberatan karena hal tersebut merupakan kewenangan Majelis Pengawas Notaris sebagaimana dimuat dalam Pasal 18 Permenkumham Nomor 15 Tahun 2020 tentang Tata Cara Pemeriksaan Majelis Pengawas Terhadap Notaris.

Selain itu, dasar hukum yang digunakan oleh Notaris M.H. tidak relevan karena Peraturan Menteri Hukum dan HAM Nomor M.02.PR.08.10 Tahun 2004 yang dijadikan acuan sudah dicabut dan tidak berlaku lagi sebagaimana dimuat dalam Pasal 60 Permenkumham Nomor 15 Tahun 2020 tentang Tata Cara Pemeriksaan Majelis Pengawas Terhadap Notaris, bahwa:

"Pada saat Peraturan Menteri ini mulai berlaku, Permenkumham Nomor M.02.PR.08.10 Tahun 2004 tentang Tata Cara Pengangkatan Anggota, Pemberhentian Anggota, Susunan Organisasi, Tata Kerja, dan Tata Cara Pemeriksaan Majelis Pengawas Notaris, dicabut dan dinyatakan tidak berlaku".

Jika kemudian Notaris M.H mendalilkan keberatannya atas penyebutan "Notaris terperiksa" dan "Notaris Terlapor" dalam BAP MPD Kota Kendari dan MPW Sulawesi Tenggara, hal ini pun menurut peneliti sudah sesuai dengan alasan bahwa:

1. MPD Kota Kendari menyebut Notaris M.H. sebagai "terperiksa" karena pemeriksaannya dilakukan berdasarkan kewenangan yang melekat pada MPD sesuai Pasal 18 UUJN, bukan karena adanya laporan sehingga penyebutan "terlapor" tidak akan tepat digunakan.

2. MPW Sulawesi Tenggara menyebut Notaris M.H. sebagai "terlapor" karena pemeriksaan yang dilakukan oleh MPW berdasarkan adanya laporan dari MPD Kota Kendari sehingga penyebutan "terlapor" sudah tepat digunakan.

Selain itu, salah satu materi banding Notaris M.H. adalah mengenai penafsiran rangkap jabatan Notaris dengan Advokat sebagaimana termuat dalam memori bandingnya ke MPP yakni bahwa yang dimaksud dengan merangkap jabatan adalah jika dia terbukti beracara secara nyata di depan pengadilan. Jika hanya disumpah dan dilantik sebagai advokat lalu mengajukan cuti selama 35 (tiga puluh lima) tahun, maka hal itu tidak melanggar UUJN.

Peneliti berpendapat bahwa yang dikemukakan oleh Notaris M.H. tidak relevan dengan UUJN karena setelah disumpah sebagai advokat, maka diinterpretasikan bahwa notaris yang bersangkutan telah mengundurkan diri sebagai notaris dan mendudukkan diri di bawah Undang-Undang Nomor 18 Tahun 2003 tentang Advokat. Pertimbangannya adalah bahwa 
secara gramatikal, kata "rangkap jabatan" dapat diartikan menduduki jabatan lain di samping jabatan tetap, atau melakukan lebih dari satu pekerjaan ${ }^{8}$. Hal ini berarti setelah resmi dilantik dan disumpah, maka yang bersangkutan secara resmi telah menduduki jabatan tersebut. Jadi jika menggunakan teori interpretasi gramatikal, rangkap jabatan terjadi pada saat dilantik dan disumpah sebagai advokat, bukan pada saat menjalankan profesi sebagai advokat di Pengadilan, Hal ini sejalan dengan interpretasi yang digunakan oleh MPW.

Merunut pada pasal-pasal yang mengatur tentang kewajiban, larangan, wewenang, dan sanksi bagi notaris yang melanggar UUJN, salah satu yang paling banyak dimuat dan disebutkan secara berulang adalah mengenai larangan untuk merangkap jabatan. Jika merujuk pada penjelasan atas frasa "rangkap jabatan sebagai advokat" hanya diberikan keterangan "cukup jelas" sehingga hal tersebut berarti frasa tersebut tidak boleh ditafsirkan lain. Hal inilah yang menjadi dasar untuk menjatuhkan sanksi administratif berupa sanksi pemberhentian dengan hormat atau pemberhentian dengan tidak hormat.

Jika dikaji menggunakan interpretasi sistematis dengan menghubungkan Pasal yang satu dengan yang lain dalam Undang-Undang Jabatan Notaris beserta peraturan pelaksananya, atau membaca penjelasan suatu perundang-undangan, maka peneliti menyimpulkan bahwa secara keseluruhan, rangkap jabatan merupakan pelanggaran berat karena di antara semua pasal-pasal yang mengatur tentang kewajiban, larangan, wewenang, dan sanksi bagi Notaris yang melanggar UUJN, salah satu yang paling banyak dimuat dan disebutkan secara berulang adalah mengenai larangan untuk merangkap jabatan dan sanksi yang dapat dikenakan terhadap Notaris yakni pada Pasal 8 ayat (1) huruf e UUJN yang menyatakan bahwa Notaris berhenti atau diberhentikan dari jabatannya dengan hormat karena merangkap jabatan sebagaimana dimaksud pada Pasal 3 huruf g.

Rangkap jabatan sebagaimana dimaksud Pasal 3 huruf g salah satunya adalah sebagai advokat. Dalam penjelasan Pasal pun disebutkan "cukup jelas" sehingga tidak dapat ditafsirkan lain. Larangan tersebut juga dimuat dalam Pasal 55 Permenkumham Nomor 19 Tahun 2019 tentang Syarat dan Tata Cara Pengangkatan, Cuti, Perpindahan, Pemberhentian, dan Perpanjangan Masa Jabatan Notaris yang menyatakan bahwa salah satu penyebab notaris berhenti atau diberhentikan dari jabatannya dengan hormat karena adalah karena merangkap jabatan sebagai pegawai negeri, pejabat negara, advokat, atau sedang memangku jabatan lain

8 Badan Pengembangan dan Pembinaan Bahasa, Kementerian Pendidikan dan Kebudayaan Republik Indonesia, "Merangkap", KBBI Daring, https://kbbi.kemdikbud.go.id/entri/Merangkap, diakses pada tanggal 3 Januari 2020 
yang oleh Undang-Undang dilarang untuk dirangkap dengan jabatan sebagai Notaris.

MPP memiliki penafsiran dan pertimbangan yang berbeda dengan MPW, yakni:

a. Notaris terlapor telah melakukan upaya hukum banding atas Putusan Majelis Pengawas Wilayah Sultra kepada MPP sesuai ketentuan yang berlaku:

b. Notaris terlapor telah mengundurkan diri sebagai advokat yang dibuktikan dengan Surat Pengunduran Diri Sebagai Advokat.

c. Sesuai ketentuan Pasal 3 ayat (2) Jo Pasal 10 Permenkumham Nomor 61 Tahun 2016 tentang Tata Cara Penjatuhan Sanksi Administratif Terhadap Notaris, bahwa penjatuhan sanksi dilakukan secara berjenjang.

d. Majelis Pemeriksa Pusat Notaris telah mempertimbangkan atas fakta-fakta hukum terhadap dalil-dalil Terlapor/Pembanding maupun Pelapor/Terbanding sebagaimana diterangkan dalam memori banding dan kontra memori banding.

Selain aspek normatif, MPP mempertimbangkan aspek substantif dan lebih menekankan fungsi pembinaan. Hal ini dilakukan demi mewujudkan salah satu tujuan hukum yakni keadilan bagi semua pihak dapat terpenuhi. Selain itu, MPP juga mempertimbangkan latar belakang Notaris, riwayat pekerjaan, perilaku, dan masa kerja notaris. Di satu sisi, aspek normatif tidak dapat diabaikan dan harus tetap dijalankan demi memenuhi mewujudkan kepastian hukum. Namun disisi lain, MPP tidak mengabaikan pertimbangan filosofis mengenai tujuan dibentuknya Majelis Pengawas Notaris yaitu untuk memberikan pembinaan kepada Notaris demi tercapainya keadilan, kemanfaatan, dan kepastian hukum.

Karena itu, MPP dengan kewenangannya menyatakan membatalkan Putusan MPW Sulawesi Tenggara dan menjatuhkan sanksi pemberhentian sementara selama 3 (tiga) bulan kepada Notaris M.H yang ditindaklanjuti dengan usulan kepada Menteri Hukum dan HAM R.I. untuk menerbitkan Surat Keputusan pemberhentian sementara selama 3 (tiga) bulan.

\section{Pertimbangan Hukum dalam Penerapan Sanksi Administratif Terhadap Notaris Rangkap Jabatan Sebagai Advokat oleh Majelis Pengawas Notaris}

Menurut Philipus M. Hadjon, sanksi merupakan alat kekuasaan yang bersifat hukum publik yang digunakan oleh penguasa sebagai reaksi terhadap ketidakpatuhan pada norma hukum administrasi. ${ }^{9}$ Sanksi pada hakikatnya merupakan instrumen yuridis yang biasanya diberikan

9 Philipis M. Hadjon, "Penegakan Hukum Administrasi dalam Kaitannya Dengan Ketentuan Pasal 20 Ayat 3 dan 4 UU No. 4 Th. 1982 tentang Ketentuan-ketentuan Pokok Pengelolaan Lingkungan Hidup", Yuridika, No. 1 Tahun XI, Januari- Pebruari 1996, hal 1. 
apabila kewajiban atau larangan yang ada dalam ketentuan hukum telah dilanggar. Hal ini sesuai dengan fungsi sanksi yang dipakai untuk penegakkan hukum terhadap ketentuan yang biasanya berisi suatu larangan atau kewajiban. Di samping itu, pemberian sanksi terhadap notaris juga untuk melindungi masyarakat dari tindakan notaris yang dapat merugikan masyarakat, misalnya membuat akta yang tidak melindungi hak-hak para pihak sebagaimana yang tersebut dalam akta notaris. Sanksi tersebut untuk menjaga martabat lembaga notaris sebagai lembaga kepercayaan, karena jika notaris melakukan pelanggaran, dapat menurunkan kepercayaan masyarakat terhadap notaris.

Perumusan sanksi administrasi harus jelas hukuman apa dikenakan terhadap perbuatan apa demi menjamin kepastian hukum bagi setiap orang. Jika rumusan peraturan tidak jelas dan multitafsir, tentu akan menimbulkan ketidakpastian hukum. Ditinjau dari segi sasarannya, dalam hukum administrasi di kenal dua jenis sanksi, yaitu:

1. sanksi reparatoir artinya sanksi yang diterapkan sebagai reaksi atas pelanggaran norma, yang ditujukan untuk mengembalikan pada kondisi semula sebelum atau menempatkan pada situasi yang sesuai dengan hukum (legale situatie), dengan kata lain, mengembalikan pada keadaan semula sebelum terjadinya pelanggaran. misalnya paksaan pemerintah (bestuursdwang), pengenaan uang paksa (dwangsom),

2. sanksi punitif artinya sanksi yang ditujukan untuk memberikan hukuman pada seseorang, misalnya adalah berupa denda administratif. ${ }^{10}$

Larangan rangkap jabatan tentunya sudah melalui kajian akademis yang mendalam. Larangan tersebut adalah usaha pencegahan agar tidak terjadi benturan kepentingan (conflict of interest). Karena jabatan notaris haruslah netral, berada di tengah-tengah tidak berpihak pada salah satu pihak. Berbeda dengan advokat yang tidak terikat kewajiban untuk bersikap netral dan dibolehkan untuk memihak salah satu pihak. Sehingga jika kemudian ada notaris yang merangkap sebagai advokat tentu bisa menimbulkan penyalahgunaan kewenangan yang berpotensi melahirkan pelanggaran hukum.

Apabila timbul perbedaan penafsiran karena adanya norma yang kabur, Majelis Pengawas Notaris dapat menggunakan teori-teori dan asas hukum umum untuk menganalisis permasalahan tersebut. Salah satu yang dapat digunakan adalah teori interpretasi yang bertujuan memecahkan suatu makna ganda, norma kabur, konflik norma hukum, dan

10 A.W. Yusuf, Sanksi Administrasi dalam Hukum Administrasi Negara, Jakarta: Pusat Perancangan UndangUndang, Badan Keahlian DPR RI, 2016, hlm. 8. 
ketidakpastian suatu perundang-undangan. Hal tersebut demi mencari dan menemukan maksud dari penormaannya. ${ }^{11}$

Selain menggunakan interpretasi gramatikal dan sistematis, MPW juga mempertimbangkan beberapa hal, di antaranya BAP dan Rekomendasi dari MPD Kendari, serta fakta-fakta hukum yang ditemukan pada saat pemeriksaan sehingga MPW menyimpulkan bahwa:

1. Notaris M.H. terbukti melanggar Pasal 17 huruf e UU Nomor 2 Tahun 2014 tentang Perubahan Atas UU Nomor 30 tahun 2004 tentang Jabatan Notaris.

2. Notaris terbukti melanggar Pasal 16 ayat (1) huruf a UUJN, kode etik dan sumpah jabatan notaris.

Berdasarkan pertimbangan tersebut, MPW menyimpulkan bahwa Notaris M.H. dikenakan sanksi administratif berupa "pemberhentian dengan hormat” sesuai Pasal 8 ayat (1) huruf e, jo. Pasal 17 ayat (1) huruf e Undang-Undang Nomor 30 Tahun 2004 sebagaimana telah diubah dengan Undang-Undang Nomor 2 Tahun 2014 tentang Jabatan Notaris, Pasal 55 Permenkumham Nomor 19 Tahun 2019 tentang Syarat dan Tata Cara Pengangkatan, Cuti, Perpindahan, Pemberhentian, dan Perpanjangan Masa Jabatan Notaris, jo. Pasal 3 ayat (3) Permenkumham Nomor 61 Tahun 2016 tentang Tata Cara Penjatuhan Sanksi Administratif terhadap Notaris.

Sedangkan MPP berpedoman pada ketentuan Pasal 3 ayat (2) Permenkumham Nomor 61 Tahun 2016 yang menyebutkan bahwa penjatuhan sanksi administratif dilakukan secara berjenjang mulai dari sanksi teringan sampai sanksi terberat sesuai dengan tata urutannya. Menurut peneliti, ayat (3) merupakan pengecualian atas ayat (2) yakni notaris yang melakukan pelanggaran yang berat terhadap kewajiban dan larangan jabatan dapat langsung dijatuhi sanksi administratif tanpa dilakukan secara berjenjang. Hal ini berarti bahwa pertimbangan MPP tidak sesuai dengan teori interpretasi sistematis bahwa penafsiran atas suatu peraturan dilakukan dengan menghubungkan pasal yang satu dengan yang lain dalam satu perundangundangan yang bersangkutan atau pada perundang-undangan hukum lainnya, atau membaca penjelasan suatu perundang-undangan sehingga kita mengerti maksudnya. Dengan kata lain, ketentuan Pasal 3 ayat (2) Permenkumham Nomor 61 Tahun 2016 harusnya dibaca secara utuh karena Pasal 3 terdiri atas 3 (tiga) ayat dan ayat-ayat dalam pasal itu merupakan satu kesatuan

11 Nyoman Nurjaya. Reorientasi Pembangunan Hukum Negara Dalam Masyarakat Multikultural Perspektif Antropologi Hukum, Pidato Pengukuhan Jabatan Guru Besar Pada Fakultas Hukum Brawijaya Malang, 2007. 
yang padu, padan, dan dimaknai secara utuh.

Jika ditabulasi, maka terdapat karakteristik yang berbeda antara Majelis Pengawas Notaris terkait Putusan Majelis Pengawas Notaris dalam menangani perkara rangkap jabatan notaris sebagai advokat yakni sebagai berikut:

Tabel 1. Karakteristik Putusan Majelis Pengawas Notaris Terkait Perkara Rangkap Jabatan Notaris sebagai Advokat Nomor AHU.24.AH.02-04 TAHUN 2020

\begin{tabular}{ccccc}
\hline $\begin{array}{c}\text { Majelis } \\
\text { Pengawas }\end{array}$ & Jenis Sanksi & $\begin{array}{c}\text { Pertimbangan } \\
\text { Hukum }\end{array}$ & $\begin{array}{c}\text { Karakteristik } \\
\text { Putusan }\end{array}$ & $\begin{array}{c}\text { Teori dan Asas yang } \\
\text { Digunakan }\end{array}$ \\
\hline MPD & Teguran tertulis & Substantif & Kuratif & Interpretasi Teleologi \\
\hline MPW & $\begin{array}{c}\text { Pemberhentian dengan } \\
\text { hormat }\end{array}$ & Normatif & Represif & $\begin{array}{c}\text { Interpretasi gramatikal } \\
\text { dan sistematis }\end{array}$ \\
\hline MPP & $\begin{array}{c}\text { Pemberhentian sementara } \\
\text { selama 3 bulan }\end{array}$ & Substantif & Kuratif & Interpretasi Teleologi \\
\hline
\end{tabular}

Berdasarkan keseluruhan paparan kasus di atas dapat dimaknai bahwa terdapat karakteristik yang berbeda dalam setiap pengambilan keputusan sesuai dengan pertimbangan dan pendekatan hukum pada setiap tingkatan Majelis Pengawas Notaris. Pendekatan yang dilakukan didasarkan bukan hanya pada aspek normatif saja, tetapi lebih ke aspek substantif. Demikian pula pada penerapan sanksinya, yang digunakan bukan hanya pendekatan secara represif, tetapi lebih ke fungsi pembinaan.

Hal ini menjadi objek kajian yang menarik dalam dunia kenotariatan, karena untuk memenuhi asas kepastian hukum, ketiga tingkatan Majelis Pengawas Notaris mengeluarkan putusan yang sama, yakni Notaris terbukti melanggar Pasal 17 e UUJN. Namun demi memenuhi asas keadilan, MPD, MPW, dan MPP menjatuhkan sanksi yang berbeda, yakni sanksi teguran tertulis, sanksi pemberhentian dengan hormat, dan sanksi pemberhentian sementara selama 3 (tiga) bulan.

\section{KESIMPULAN}

Majelis Pengawas Notaris diberikan wewenang pengawasan dan pembinaan terhadap perilaku dan pelaksanaan jabatan notaris oleh Undang-Undang, termasuk di dalamnya penjatuhan sanksi administratif terhadap notaris yang terbukti melakukan rangkap jabatan sebagai advokat. Pertimbangan hukum Majelis Pengawas Notaris dalam menjatuhkan sanksi administratif terhadap notaris berbeda antara MPD, MPW, dan MPP. Pertimbangan dan pendekatan hukum yang digunakan bukan hanya berdasar pada aspek normatif saja, tetapi juga aspek substantif dengan menggunakan teori, asas, dan prinsip hukum yang berlaku. Demikian 
pula pada penerapan sanksinya, yang digunakan bukan hanya pendekatan secara represif, tetapi lebih ke fungsi pembinaan demi mencapai tujuan hukum.

\section{Daftar Pustaka}

\section{Buku}

Dewa, Muh. Jufri, Hukum Administrasi Negara dalam Perspektif Pelayanan Publik, Kendari: Unhalu Press, 2011.

Nurjaya, Nyoman. Reorientasi Pembangunan Hukum Negara Dalam Masyarakat Multikultural Perspektif Antropologi Hukum, Pidato Pengukuhan Jabatan Guru Besar Pada Fakultas Hukum Brawijaya Malang, 2007.

Yusuf, A.W., Sanksi Administrasi dalam Hukum Administrasi Negara, Jakarta: Pusat Perancangan Undang-Undang, Badan Keahlian DPR RI, 2016.

Wingyosoebroto, Soentandyo, Penelitian Hukum, Surabaya, Surabaya: Pusat Studi Hukum dan Pembangunan Fakultas Hukum UNAIR, 1974.

Marzuki, Peter Mahmud, Penelitian Hukum, edisi revisi cetakan Ke-13, Jakarta: Kencana, 2017.

\section{Jurnal dan Makalah}

Cahyanti, Nur, Budi Raharjo, Sri Endah Wahyuningsih, "Sanksi Terhadap Notaris Yang Melakukan Tindak Pidana Menurut Peraturan Perundang-Undangan di Indonesia", Jurnal Akta, Volume 5, Nomor 1, Maret 2018.

Fatmalina, Arifa, Roesnatiti Prayitno, Widodo Suryandono, "Notaris yang Berulang Kali Melakukan Pelanggaran Setelah Dijatuhi Sanksi oleh Majelis Pengawas Notaris (Analisis Putusan Majelis Pemeriksa Pusat Notaris Tanggal 09 Oktober 2018 Nomor 03/B/MPPN/X/2018 dan Putusan Majelis Pemeriksa Wilayah Notaris Provinsi Jawa Barat Tanggal 26 Februari 2007 Nomor 129/MPW-JABAR/2007)", Notary Indonesian Universitas Indonesia, Vol 1, No 002, 2019.

Hadjon, Philipis M., “Penegakan Hukum Administrasi dalam Kaitannya Dengan Ketentuan Pasal 20 Ayat 3 dan 4 UU No. 4 Th. 1982 tentang Ketentuan-ketentuan Pokok Pengelolaan Lingkungan Hidup", Yuridika, No. 1 Tahun XI, Januari- Pebruari 1996.

\section{Peraturan Perundang-undangan}

Undang-Undang Nomor 30 Tahun 2004 tentang Jabatan Notaris 
Undang-Undang Nomor 2 Tahun 2014 tentang Perubahan Undang-Undang Nomor 30 Tahun 2004 tentang Jabatan Notaris

Peraturan Menteri Hukum dan Hak Asasi Manusia Nomor 61 Tahun 2016 tentang tata Cara Penjatuhan Sanksi AdministratifTerhadap Notaris.

Peraturan Menteri Hukum dan Hak Asasi Manusia Nomor 19 Tahun 2019 tentang Tata Cara Pengangkatan, Cuti, Perpindahan, Pemberhentian, dan Perpanjangan Masa Jabatan Notaris.

Peraturan Menteri Hukum dan Hak Asasi Manusia Nomor 15 Tahun 2020 tentang Tata Cara Pemeriksaan Majelis Pengawas Notaris Terhadap Notaris.

\section{Situs web}

Badan Pengembangan dan Pembinaan Bahasa, Kementerian Pendidikan dan Kebudayaan Republik Indonesia, "Merangkap", KBBI Daring, https://kbbi.kemdikbud.go.id/entri/Merangkap, diakses pada tanggal 3 Januari 2020. 